\title{
Evaluation of the Relationship between Internet Addiction and the Thoracal Kyphosis Angle on Medical Faculty Students
}

\section{Tıp Fakültesi Öğrencilerinde İnternet Bağımlılığının Torakal Kifoz Açısı ile îlişskisinin Değerlendirilmesi}

\author{
(D)Keziban Karacan', (D) Halit Çelik', @Mehtap Erdoğan' \\ 1 Departmant of Anatomy, Faculty of Medicine, University of Sakarya, Turkey
}

\begin{abstract}
Aim: For the last 20 years, various problems caused by internet has brought attention to researchers. People who actively use the Internet can spend 40 to 80 hours per week on a computer or phone. Their sleep patterns, daily life and exercise habits change over time. These changes bring along some illnesses such as back pain, neck pain and carpal tunnel syndrome. Many of these ailments underlie postural disorders. The most common of these postural disorders is increased thoracic kyphosis. Our aim is to determine the effect of internet usage on thoracic kyphosis angle in healthy individuals.

Material and Method: We conducted our study in 322 ( $K=152$, $E=170$ ) students who were educated at Sakarya University Medical Faculty. Internet usage questionnaire was applied to the participants to measure the level and duration of internet usage. Thoracic kyphosis angle measurement was done with Flexicurve device Statistical comparisons were made using SPSS software.

Results: In our study, the kyphosis angles of the participants varied between 21,067 degrees and 49,546 degrees. The average score of the questionnaire on internet usage was 32,508 (slightly dependent), while the average daily internet use was 200 minutes. When the questionnaire scores and kyphosis angle values were compared, the result was statistically significant $(p=0.016, p<0.05)$.

Conclusion: It is important to identify and evaluate the negative effects of internet use on our posture. People should pay attention to internet usage times and body postures during use in order to protect their postures during internet use. Otherwise, there will be an increase in thoracic kyphosis angle with serious disorders in the posture.
\end{abstract}

Keywords: Thoracic angle, kyphosis, internet addiction, flexicurve
Öz

Amaç: İnternetin beraberinde getirdiği sorunlar son 20 yıl boyunca araştırmacılar tarafından da ilgi odağı olmuştur. İnterneti aktif olarak kullanan kişiler bilgisayar veya telefon başında haftalık 40 ila 80 saate tekabül eden süreler geçirebilmektedirler. Bu kişilerin zamanla uyku düzenleri, gündelik hayat ve egzersiz alışkanlıkları değişmektedir. Bu değişimler beraberinde sırt ağrısı, boyun ağrısı, karpal tünel sendromu gibi bazı rahatsızıkları getirmektedirler. Bu rahatsızıkların birçoğunun temelinde postüral bozukluklar yatmaktadır. Bu postüral bozukluklardan en sık karşılaşanı torakal kifoz artışıdır. Bizim amacımız sağlıklı bireylerde internet kullanımının torakal kifoz açısı üzerindeki etkisini saptamaktır.

Gereç ve Yöntem: Çalışmamızı Sakarya Üniversitesi Tıp Fakültesinde eğitim alan toplam 322 (K=152, E=170) öğrencide gerçekleştirdik. Katılımcılara internet kullanım düzeyi ve süresini ölçmek amacı ile İnternet kullanım anketi uygulandı. Torakal kifoz açısı ölçümü Flexicurve cihazı ile yapıldı. Cihaz C7-T12 omurgaları arasına yerleştirilip daha sonra milimetrik kâğıda geçirildi ve ortaya çıkan şeklin açı değeri özel bir formül ile hesaplandı. İstatistiksel karşılaştırmalar SPSS paket programı kullanılarak yapıldı.

Bulgular: Çalışmamızda katılımcılarının kifoz açıları 21,067 derece ile 49,546 derece arasında değişmekteydi. İnternet kullanımı ile ilgili anketin ortalama puanı 32,508 (az bağımlı) iken günlük internet kullanım ortalaması ise 200 dakikaydı. Anket puanları ile kifoz açısı değerleri karşılaştııılığında ortaya çıkan sonuç istatiksel olarak anlamlıydı $(p=0,016, p<0.05)$.

Sonuç: Internet kullanımının postürümüz üzerindeki negatif etkilerini saptamak ve değerlendirmek önemlidir. Kişilerin internet kullanımları sırasında postürlerini korumak amacıyla internet kullanım sürelerine ve kullanım sırasındaki vücut duruşlarına dikkat etmeleri gerekmektedir. Aksi takdirde postürde ciddi bozukluklar ile birlikte torakal kifoz açısında bir artış ortaya çıkmaktadır.

Anahtar Kelimeler: Torakal açı, kifoz, internet bağımlılı̆ı, flexicurve

Corresponding (IIletişim): Keziban Karacan, Department of Anatomy, Faculty of Medicine, University of Sakarya, the Neighborhood of Korucuk, the Campus of Korucuk, Adapazarı, Sakarya, Turkey

E-mail (E-posta): kkaracan@sakarya.edu.tr

Received (Geliş Tarihi): 08.09.2020 Accepted (Kabul Tarihi): 21.10.2020 


\section{INTRODUCTION}

The Internet occupies a large place in our lives in many sectors such as information, communication, and shopping, and is increasing its popularity day by day in whole world. However, it also brings some problems with individuals. ${ }^{[1]}$

For the last 20 years, various problems caused by internet has brought attention to researchers. Dr. Kimberly Young ${ }^{[3]}$ has defined excessive internet use in individuals as internet addiction and used the Internet Addiction Test created by him to determine this. This test is widely used in research on the subject today. ${ }^{[2]}$ People with high internet usage can spend 40 to 80 hours a week on their computer or phone to use the internet. Their sleep patterns, daily life and exercise habits change over time. These changes bring along some conditions such as back pain, neck pain and carpal tunnel syndrome. Many of these ailments underlie postural disorders. ${ }^{[3]}$

Posture is that every part of the body is in the position adjacent to the body and the most stable compared to the whole body. It is also described as the combination of positions with joints in every movement we perform with our body. ${ }^{[4]}$ Some factors such as race, gender, daily habits, the conditions that the world has put before us, the occupation and psychology of the person, the exercise factor, and the discomfort that a person experiences in his life affect posture formation. Especially daily life habits are one of the most important factors affecting posture. People who spend a long time at the computer or on the phone begin to acquire a distorted posture, called the forward head posture, in front of the spinal center of gravity. ${ }^{[5]}$ The forward head posture causes a strain on the neck. As a result of stretching, a mechanical stress occurs in the region, which causes an imbalance in the muscles in the region ${ }^{[6]}$ Muscle imbalance; Rolling shoulders reveal a synchronous postural disorder including increased shoulder elevation, increased thoracic kyphosis and forward head posture. In this postural disorder, the Cervical and Thoracic vertebrae are primarily affected. ${ }^{[7]}$ As the vertebrae are affected, an increase in thoracic kyphosis angle is observed. Normal thoracic kyphosis angle value varies between $20^{\circ}$ and $40^{\circ}$. This value is called hypokyphosis (flatback) if it is below 20 degrees, and hyper kyphosis if it is above 40 degrees. While the normal kyphosis angle varies between 20-40 degrees in young individuals, this value varies between 20-48 degrees in women and 20-44 degrees in men. ${ }^{[8,9]}$

The mean kyphosis angle has been defined as $37^{\circ} \pm 9^{\circ}$ and this has been confirmed in many studies. Thoracic hypokyphosis is biomechanically studied in 5 different forms: Scheuermann's disease, Postural Kyphosis, Congenital Kyphosis, Age-related Hyper kyphosis, Neurological Hyper kyphosis. The most common of these is postural kyphosis. Postural kyphosis is a disorder that results from weakening of the muscles and ligaments affecting the spine due to wrong postural habits, without causing any visible damage to the vertebrae. ${ }^{[10,11]}$ In our study, the type of kyphosis that we will associate with the use of the internet is Postural Kyphosis.

There are many publications in the literature regarding internet use and thoracic kyphosis. However, the number of publications that relate the use of the internet to the thoracic kyphosis angle is limited. Therefore, in our study, we aimed to determine the relationship between internet use and thoracic kyphosis angle in Sakarya University medical students.

\section{MATERIAL AND METHOD}

We conducted our study in $322(F=152, M=170)$ students who were educated at Sakarya University Medical Faculty. Ethics committee approval was obtained before starting our measurements (71522473/050.01.04/452), and a voluntary consent form was obtained from the participants during the application. Our study did not include those with any physical or mental disabilities, those who had undergone surgical operations that could affect the spine indirectly or directly, those with shoulder impingement syndrome, diagnosed disc hernias and duct narrowing. Our experiement (the thoracic kyphosis measurements and internet usage test) was conducted using the flexicurve device on the participants. Before starting the study, the researchers who took the measurement made many trial measurements in order to gain experience and to identify possible unexpected situations and after being completely confident, the measurements were then made on the students. On the measurement basis, a participant was asked to stand straight, looking back and naturally and normally as in his daily life. Afterwards, certain reference points (C7-T12-L4) were determined by palpation method. To determine the T12 point, the crista iliaca section of Os coxae was palpated. Then the right middle of the upper boundaries of the right and left crista iliaca was determined as the processes spinosus of the $4^{\text {th }}$ Lumbar vertebra and palpated upward and marked by the processus spinosus of the $12^{\text {th }}$ thoracic vertebra. The processus spinosus of the $7^{\text {th }}$ cervical vertebra was also determined and marked by palpation method. After these markings were made, the Flexicurve device was placed between C7-T12 and the device was pressed in such a way that it does not disturb the patient's balance in order to take the shape of the person's spine and completely touch the patient's thoracic region (Figure1). The resulting shape was immediately transferred to the millimeter graph paper we fixed on the table with a wooden pen. After the figure was created properly, the E, L1, $L 2$ and $L$ values, shown in Figure 1, were carefully measured with the normal ruler. After the measurement, the Kyphosis angle was calculated with the mathematical formula (arc tan (E/L1) $+\arctan (E / L 2))$ shown in Figure 2.

After the measurement process of the participants was completed, the participants were given a questionnaire called Internet Usage Test and asked to be filled in objectively. 


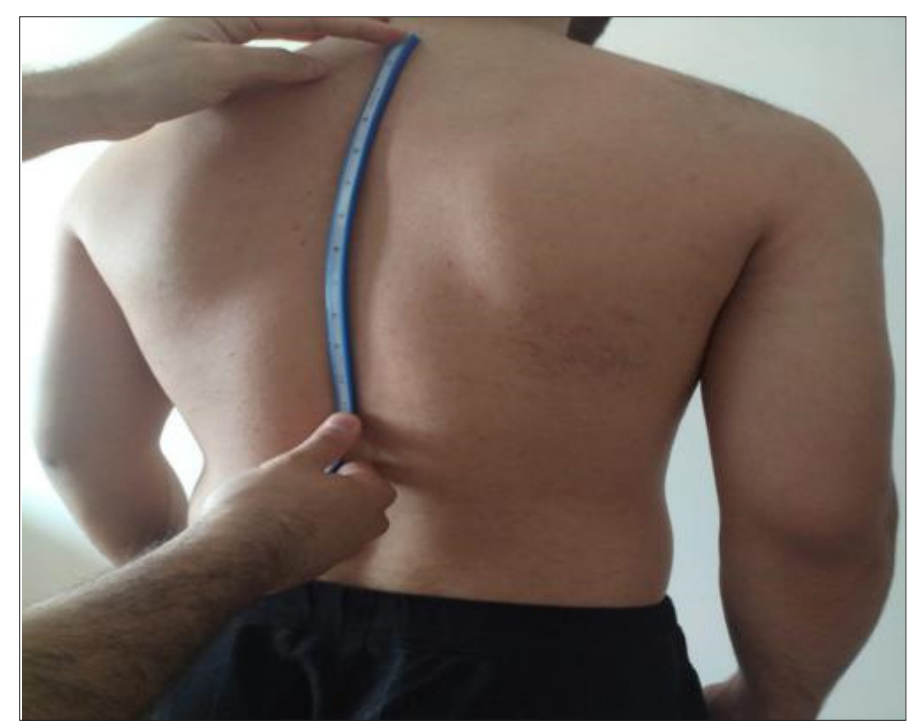

Figure 1. Flexicurve device on the participant use of

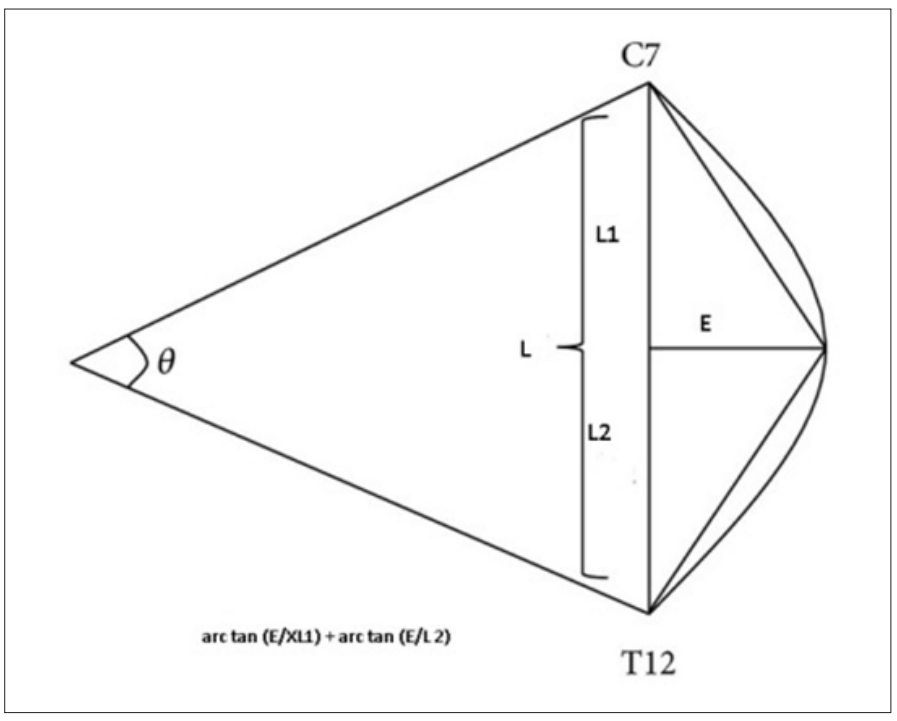

Figure 2. Mathematical formula showing how kyphosis angle is calculated (C7 represents 7. cervical vertebrae, T12 represents 12 . Thoracic vertebrae, $\Theta$ represents the thoracic kyphosis angle, A represents the most protruding point (Apex) of the thoracic part of the spine)

\section{Internet Usage Test}

Internet usage test It was created by Kimberly Young ${ }^{[3]}$ and is used to detect internet addiction. The test contains 20 questions and the answer range of each question is between 0 and 5 ( 0 =never; 1 =rarely; 2 =sometimes; 3 =often; 4 =very often, 5 =always). At the end of the test, the score range varies between 0 and 100. In this context, the results from 0 to 19 show that there is no excess in internet use, and results from 20 to 39 indicate low level internet use. Results from 40 to 69 indicate medium level internet usage, while results from 70 to 100 indicate high level internet usage. We determined participant with 0-19 as $1^{\text {st }}$ group, 20-39 as $2^{\text {nd }}$ group, 40-69 as $3^{\text {rd }}$ group, and $70-100$ points as $4^{\text {th }}$ group. The results in our study were determined and recorded in this way.

\section{Statistical Analysis}

All obtained data were analysed by utilising "Statistical Packages fort he Soial Science" (SPSS) 21 statistics program on a computer. After administrating descriptive statistical analyses (frequency, percentage distribution, mean \pm standart deviation), normal distribution of continuous variable was assessed by Shapiro-Wilk and Kolomogrov Smirnov Tests. Chisquare test sor Fisher Exact test were conducted in order to evaluate the group difference in terms of discrete variables, and $<0,05$ value was accepted statistically significant.

\section{RESULTS}

The kyphosis angles of 170 male and 152 female participants in our study ranged from $21,067^{\circ}$ to $49,546^{\circ}$ $(x \pm s=34,570 \pm 5,135)$ (Table 1). The average kyphosis angle in men was found to be $33.825^{\circ}$, whereas the average kyphosis angle in women was $35.405^{\circ}$ (Table 2). When we compare it by gender factor, the average kyphosis angle in men is lower than women and this difference is statistically significant ( $p$ : 0.006).

Table 1. Display of minimum, maximum values. arithmetic mean and standard deviations of the resulting results

\begin{tabular}{lccc} 
& Min & Max & Mean \pm std \\
\hline Kyphosis Angle & $21.067^{\circ}$ & $49.546^{\circ}$ & $34.570 \pm 5.135$ \\
Survey Score & 0.000 & 100.000 & $32.508 \pm 15.572$ \\
Internet Usage Time & $20 \mathrm{~min}$. & $600 \mathrm{~min}$. & $200.87 \pm 47.858$ \\
Body Mass Index & 16.286 & 37.040 & $23.689 \pm 14.866$ \\
\hline
\end{tabular}

Table 2. Display of average values of kyphosis angle and survey scores according to gender factor

\begin{tabular}{lccc} 
& $\begin{array}{c}\text { Man } \\
\text { (N:170) }\end{array}$ & $\begin{array}{c}\text { Woman } \\
\text { (N:152) }\end{array}$ & P Value \\
\hline Kyphosis Angle & $33.825^{\circ}$ & $35.405^{\circ}$ & ${ }^{*} 0.006$ \\
Survey Score & 33.664 & 31.215 & ${ }^{*} 0.184$ \\
\hline${ }^{*} \mathrm{p}<0,005$ statistically significant. & & & \\
\hline
\end{tabular}

Internet usage questionnaire scores of the participants ranged from 0 to 100 points ( $x \pm s=32,508 \pm 15,572$ ) (Table 1). While this average is 33,664 in men, it is 31,215 in women (Table 2). When we compare the scores by gender factor, it was seen that the resulting value was statistically insignificant (p: 0.184).

In our study, when the internet usage survey scores and kyphosis angle values were compared, the result was statistically significant (p: 0.016).

When the internet usage levels and kyphosis angle values were compared, the result was not found statistically significant (0.055). Table 3 shows the Internet usage levels and kyphosis angles average values.

In our study, the internet usage time of the participants varied between 20 minutes and 600 minutes per day and the 
average was found as 200.87 minutes/day. While this average is $204.70 \mathrm{~min} /$ day for women, it is $197.44 \mathrm{~min} /$ day for men. When the internet usage times are compared by gender factor, the result is statistically insignificant ( $p: 0,507)$.

In addition, body mass index values ranged between 16,286 and 37,040 , and the average value was calculated as 23,689. While the average BMI value of men was found to be 23.709 , this value was found to be 21.757 for women.

\section{DISCUSSION}

We cannot ignore the fact that the internet occupies a place in our lives in many sectors in today's world and its popularity is increasing day by day. This fact brings us many benefits as well as some problems. It is very important to detect and evaluate the disorders brought by the Internet. Among these disorders, postural disorders caused by internet use are at the top of the list. During the use of the Internet, people cannot maintain their postures properly and after having access to the internet, they have difficulty leaving the environment and returning to normal life. This situation causes serious changes in the posture. One of these postural disorders is increased thoracic kyphosis.

In our study, we found the mean thoracic kyphosis angle as $34,570 \pm 5,135$ degrees and found that there was a significant relationship between thoracic kyphosis angle and both internet addiction and duration of internet use. The reason for the increase in thoracic kyphosis angle value with the internet usage time is that people cannot maintain their body postures during the internet use. When we look at the literature, there are publications showing the effects of computer, telephone and internet use on posture. ${ }^{[12,13]}$ Büyükturan et al. ${ }^{[14]}$ in their study on 113 female participants using the spinal mouse device, they determined the thoracic kyphosis angle as $51.63 \pm 11.42$. Büyükturan and her friends attributed the mean kyphosis angle to be higher than the normal values between 20 and 40 , similar to our hypothesis, the participants were university students, and the time spent at the desk and the use of smart devices were higher. However, this value is much higher than the values in our study and in many studies in the literature. ${ }^{[8-10]}$

When we evaluated by gender factor in our study, the mean thoracic kyphosis angle in women was significantly higher than in men. Goh et al. ${ }^{[15]}$ with the study of 220 radiographic images, and Fon. et al. ${ }^{[16]}$ the results of their study using 316 radiographic images are similar to ours. In both studies, the mean kyphosis angle in women was higher than in men, and this difference was emphasized to be statistically significant. This difference is attributed to women living a more inactive life than men. Our observation is similarly that the female participants in our study are more inactive. It has also been emphasized in publications that the force of the back extensors in women is affected by the high release of estrogen hormone, which increases the angle of thoracic kyphosis. ${ }^{[17]}$
Contrary to many studies in the literature and our study, Kargarfard et al. ${ }^{[18]}$ conducted an analysis of spinal curvatures using the flexicurve device on 1448 participants ( 730 females and 718 males), with an average kyphosis angle of $28.20 \pm 12.78^{\circ}$ in women and $31.87 \pm 10.70^{\circ}$ in men and stressed that this difference was statistically significant. ${ }^{[8]}$

In fact, in many studies ${ }^{[19-21]}$ on thoracic kyphosis angle, the sample size was kept narrow (Table 4). Nadri et al. ${ }^{[19]}$ the study examining the relationship between thoracic kyphosis angle and low back pain among dentists in Iran was carried out with 84 participants. In their study, they found that there was a significant relationship between thoracic kyphosis angle and study experience, and emphasized that this angle was higher in women, similar to our study.

\begin{tabular}{lccc}
\hline \multicolumn{4}{l}{ Table 4. Comparison of the sample size in 4 study } \\
& Number of Female & Number of Male & Total \\
\hline Our Study & 152 & 177 & 322 \\
Hamed Nahri's Study & 35 & 43 & 78 \\
Eva Barrett's Study & 4 & 7 & 11 \\
Daniel M. Grindle's Study & 22 & 18 & 40 \\
\hline
\end{tabular}

When we look at the studies revealed in the literature, one thing that draws our attention is that the flexicurve device used throughout the study was never changed. ${ }^{[22,23]}$

While we were carrying out our study, we continued with a new flexicurve device every 50 measurements, considering that the device would lose its ability to take shape over time.

Radiographic measurements are also frequently encountered in publications, and their validity has been validated, but the fact that this measurement technique emits radiation and is more expensive than the flexicurve device cannot be ruled out. ${ }^{[24]}$ It is also emphasized that there is a deviation of $\pm 5^{\circ}$ even in the cobb angle method, which is described as the gold standard. ${ }^{[25]}$ Carman et al. ${ }^{[26]}$ they revealed that radiographic measurements may also vary depending on the observer performing the measurement. In their study, 5 different observers (4 orthopedists and 1 physiotherapist) made thoracic kyphosis angle measurements on the same radiographic images. For each radiographic measurement, 2 calculations were made and then the calculations were compared. In the calculation of thoracic kyphosis angle, they found the mean absolute value of the difference between the observers to be 3.3 degrees and reported that 95 percent of the differences were 7 degrees (0-30) or less. When we look at all these studies; It is important to identify and evaluate the negative effects of internet use on our posture. People should pay attention to internet usage times and body postures during use in order to protect their postures during internet use, otherwise an increase in thoracic kyphosis angle is observed. In order to prevent thoracic kyphosis increase, individuals can pay attention to internet usage time and body postures as well as strengthening their back muscles and stretching exercises in the pectoral region. When measuring 
thoracic kyphosis angle, the flexicurve device we used has revealed results close to the values in the literature and can be used when evaluating the spinal curvatures when ease of use is also considered.

As the limitations of our study; In our study conducted with 322 (170M 152F) participants, when we divided the internet usage survey scores into 4 groups according to the internet usage levels, only 6 participants were included in the 4th group, which caused the statistical results to be meaningless when comparing the internet usage level and thoracic kyphosis angle. In this context, keeping the number of participants at a certain rate can contribute to the creation of more accurate and objective results. It is also a matter of debate how objective the participants are when completing the Internet usage survey. We think that in publications about internet addiction, people tend to hide their internet use from their environment and some participants may not have filled the questionnaires objectively.

\section{CONCLUSION}

As a result of our study, when we examined all the findings, we came to the conclusion that internet use has a negative effect on thoracic kyphosis angle and this should be evaluated and determined.

\section{ETHICAL DECLARATIONS}

Ethics Committee Approval: The study was carried out with the permission of Medical Faculty Ethics Committee of Sakarya University (Permission granted: 2020, Decision no: 71522473/050.01.04/452).

Informed Consent: All patients signed the free and informed consent form.

Referee Evaluation Process: Externally peer-reviewed.

Conflict of Interest Statement: The authors have no conflicts of interest to declare.

Financial Disclosure: The authors declared that this study has received no financial support.

Author Contributions: All of the authors declare that they have all participated in the design, execution, and analysis of the paper, and that they have approved the final version.

Acknowledgement: We would like to thanks Sakarya University medical students who voluntarily participated in our study.

\section{REFERENCES}

1. Cerniglia L, Zoratto F, Cimino S, Laviola G, Ammaniti M, Adriani W. Internet Addiction in adolescence: Neurobiological, psychosocial and clinical issues. Neurosci Biobehav Rev 2017;76:174-84.

2. Černja I, Vejmelka L, Rajter M. Internet addiction test: Croatian preliminary study. BMC Psychiatry 2019;19:388.

3. Young KS. Internet addiction: Symptoms, evaluation, and treatment innovations in clinical practice. In L. VandeCreek, \& T. L. Jackson (Eds.), Sarasota, FL: Professional Resource Press. 17th ed. 1999

4. Haslegrave CM. What do we mean by a 'working posture'?. Ergonomics. 1994;37:781-99.
5. Kang JH, Park RY, Lee SJ, Kim JY, Yoon SR, Jung KI. The effect of the forward head posture on postural balance in long time computer based worker. Ann Rehabil Med 2012;36:98-104.

6. Waris P. Occupational cervicobrachial syndromes. A review. Scand J Work Environ Health. 1979;5:3-14.

7. Moore MK. Upper crossed syndrome and its relationship to cervicogenic headache. J Manipulative Physiol Ther 2004;27:414-20.

8. Fon GT, Pitt MJ, Thies AC Jr. Thoracic kyphosis: range in normal subjects. AJR Am J Roentgenol. 1980;134:979-83.

9. Kado DM, Prenovost K, Crandall C. Narrative Review: Hyperkyphosis in Older Persons. Ann Int Med 2007;147:330-8.

10. Mauroy JC. Kyphosis Physiotherapy From Childhood to Old Age. Inphysical Therapy Perspectives in The 21st Century-Challenges And Possibilities. [updated 5 May 2020;cited:19 Agust 2020]. Available from: www.IntechOpen.com

11. Perriman DM, Scarvell JM, Hughes AR, Lueck CJ, Dear KB, Smith PN. Thoracic Hyperkyphosis: A Survey of Australian Physiotherapists. Physiother Res Int 2012;17:167-78.

12. Asundi K, Odell D, Luce A, Dennerlein JT. Notebook computer use on a desk, lap and lap support: effects on posture, performance and comfort. Ergonomics 2010;53:74-82.

13. Gerr F, Monteilh CP, Marcus M. Keyboard use and musculoskeletal outcomes among computer users. J Occup Rehabil 2006;16:265-77.

14. Büyükturan B, Karartı C, Özsoy I, Ceylan I, Büyükturan Ö. Torakal ve lumbal eğrilikler ile gövde kaslarının güç ve enduransı arasındaki ilişkinin incelenmesi. Süleyman Demirel Üniversitesi Sağlık Bilimleri Derg 2019;10:88-92.

15. Goh S, Price RI, Song S, Davis S, Singer KP. Magnetic resonance-based vertebral morphometry of the thoracic spine: age, gender and levelspecific influences. Clin Biomech (Bristol, Avon). 2000;15:417-25.

16. Fon GT, Pitt MJ, Thies AC Jr. Thoracic kyphosis: range in normal subjects. AJR Am J Roentgenol 1980;134:979-83.

17. Sinaki M, Itoi E, Rogers JW, Bergstralh EJ, Wahner HW. Correlation of back extensor strength with thoracic kyphosis and lumbar lordosis in estrogen-deficient women. Am J Phys Med Rehabil 1996;75:370-4.

18. Kargarfard M, Mahdavınezhad R. Assessment of Spınal Curvature in Isfahan Unıversıty Students. Journal of Isfahan Medical School 2010;102:762-76.

19. Nadri H, Rohani B, Teimori G, Vosoughi S, Fasih-Ramandi F. Thoracic Kyphosis Angle in Relation to Low Back Pain among Dentists in Iran. Open Access Maced J Med Sci. 2019;7:3704-9.

20. Barrett E, Lenehan B, O'sullivan K, Lewis J, McCreesh K. Validation of the manual inclinometer and flexicurve for the measurement of thoracic kyphosis. Physiother Theory Pract. 2018;34:301-8.

21. Grindle DM, Mousavi SJ, Allaire BT, White AP, Anderson DE. Validity of flexicurve and motion capture for measurements of thoracic kyphosis vs standing radiographic measurements. JOR Spine. 2020;3:e1120.

22. Azadinia F, Kamyab M, Behtash H, Saleh Ganjavian M, Javaheri MR. The validity and reliability of noninvasive methods for measuring kyphosis. J Spinal Disord Tech. 2014;27:E212-E218.

23. Burton AK. Regional lumbar sagittal mobility; measurement by flexicurves. Clin Biomech (Bristol, Avon). 1986;1:20-6.

24. Doody MM, Lonstein JE, Stovall M, Hacker DG, Luckyanov N, Land CE. Breast cancer mortality after diagnostic radiography: findings from the U.S. Scoliosis Cohort Study. Spine (Phila Pa 1976) 2000;25:2052-63.

25. Morrissy RT, Goldsmith GS, Hall EC, KehI D, Cowie GH. Measurement of the Cobb angle on radiographs of patients who have scoliosis. Evaluation of intrinsic error. J Bone Joint Surg Am. 1990;72:320-7.

26. Carman DL, Browne RH, Birch JG. Measurement of scoliosis and kyphosis radiographs. Intraobserver and interobserver variation. J Bone Joint Surg Am. 1990;72:328-33. 